\title{
David Mabberley and Australian botany
}

\author{
B. G. Briggs \& K. L. Wilson \\ National Herbarium of New South Wales, \\ Royal Botanic Gardens and Domain Trust, \\ Mrs Macquaries Road, Sydney, NSW 2000, Australia. \\ barbara.briggs@rbgsyd.nsw.gov.au
}

\begin{abstract}
David Mabberley has worked on five continents but chose Australia as his home, moving there in 1996. By then, he already had an outstanding international reputation and his contributions to Australian botany and Australian botanical history had started with his biographies of botanist Robert Brown and botanical artist Ferdinand Bauer. Joseph Banks, Brown and Bauer have remained continuing interests for him with further publications and lectures. In Australia he has contributed to the treatments of Meliaceae and Rutaceae in the Flora of Australia, drawn attention to the work of John Bidwill and other botanical figures, established important collaborations on the phylogeny and diseases of Citrus, investigated Red Cedar (Toona ciliata), given master classes in economic botany, and much more. Moving to Australia did not deflect David from his global reach in tropical botany, the world's flora in The Plant-book, and economically important plants. He has contributed greatly to Australian botany, but his career of outstanding achievement continues to be global, not limited to a single continent.
\end{abstract}

Keywords. Australia, Ferdinand Bauer, John Bidwill, Joseph Banks, Robert Brown, systematic botany

\section{Introduction}

As a researcher and educator, David Mabberley has worked on five continents, including both the Old and the New World tropics. He was based in Britain, his birthplace, for the early stages of his career but he later chose Australia as his home. He first visited briefly in 1974 after fieldwork in Papua New Guinea and moved to Australia in 1996. Since then he has continued a career of outstanding achievement. There was previously a substantial Australian element in his studies, but this intensified after his move to Sydney.

In 1996 David already had a formidable international reputation and his publication list was truly impressive. There were two editions of a book on tropical rain forest ecology (Mabberley, 1983, 1991), the text for the second completed on a Polish freighter sailing from Europe to Sydney in 1989, on his way to take up a visiting scholarship at the University of Sydney. He had also published a masterly biography of Robert Brown (Mabberley, 1985), a treatment of Meliaceae for the Flora Malesiana (Mabberley et al., 1995), and had taken on the world's plants in The Plant-book. A portable dictionary of the higher plants (Mabberley, 1987), as well as publishing many papers in scientific journals. David had done extensive fieldwork in Africa, Asia and 
Australasia, and been Dean of Wadham College for ten years, keeper of the excellent Wadham College gardens, and curator of the Oxford University Herbaria.

Moving to Australia has made little change in the directions or pace of David's research. He has continued research and publication in systematic botany, economic botany, botanical history and botanical art.

\section{Robert Brown and Ferdinand Bauer, the Investigator voyagers}

David has had a long-term fascination with Sir Joseph Banks and his protégés, particularly those who visited or lived in colonial Australia. His practical knowledge of botany has been combined with extensive historical 'detective work' investigating and interpreting archival materials in many herbaria, museums and libraries, particularly in London, Vienna and Sydney. In his biography of Brown, Jupiter Botanicus (Mabberley, 1985), David set Robert Brown's Australian botany in the context of his life and the global range of his work, with a detailed account of the Investigator voyage around Australia and Brown's time in the colony. After the voyage, Brown (1810a) had included some 2000 Australian species in his Prodromus, three quarters of them newly described (Stearn, 1960). This was a huge advance in knowledge of Australia's flora. William Stearn (1960) and David both emphasised the importance of the Prodromus also for adopting the then modern system of classification of Jussieu (1789) rather than the sexual system of Linneaus.

After the Prodromus, Brown was repeatedly drawn back to Australian botany, as covered by David in his account of Brown's life and work. On the Proteaceae of Jussieu (Brown, 1810b) was a masterful account of a family important in the Australian flora. It is a significant contribution to the systematics and morphology of Proteaceae, the floristics of Australia, and notable also for its application of palynology to systematics. It included 18 new genera, and nearly all of these are still upheld. Other publications on Australian botany by Brown included his Appendix to Flinders' journal (Brown, 1814), description of Kingia (Brown, 1826), the Supplementum primum to the Prodromus (Brown, 1830), description of the botany 'of the vicinity of Swan River' [the present-day Perth region] (Brown, 1831), a botanical appendix to Captain Sturt's expedition (Brown, 1848) and more [as discussed by Mabberley (1985)]. For Brown, these studies and publications were interspersed with monographs, his preferred style of work, and his microscopic observations on 'Brownian motion' and the cell nucleus. In Jupiter Botanicus, David thoroughly and expertly assessed the context and significance of each.

Ferdinand Bauer's paintings of plants and animals from the Investigator voyage around Australia are outstanding examples of botanical and zoological art (Watts et al., 1997; Mabberley, 1999a). He was 'perhaps the greatest natural history artist ever to work in the field - as opposed to merely the studio' (Mabberley, 2017a). In his publications on the career and art of Bauer (Mabberley, 1999a, 2017a; Mabberley \& Moore, 1999; Pignatti-Wikus et al., 2000) and in lectures, David has described the unique numbering system Bauer used in the field to record about 1,000 colours so that 
his drawings could become brilliant paintings completed much later in London. He has collaborated on two major exhibitions of Bauer's art in Sydney: in 1997 at the Museum of Sydney (Watts et al., 1997) and the State Library of New South Wales in 2017 (Fig. 1). For Painting by numbers: the life and art of Ferdinand Bauer (Mabberley, 2017a), he was awarded the John Thackray Medal for 2018 of the Society for the History of Natural History. In the Society's newsletter, it was described as 'a marvellous work that has answered, with great conviction, a long-standing unanswered question. How did Bauer manage to achieve, in his final finished works, such beautiful colour accuracy, given that some of his field sketches had been made many years previously?'

The bicentenary of Matthew Flinders' circumnavigation of the continent on the Investigator in 1801-1803, with Robert Brown as naturalist and Ferdinand Bauer as natural history artist, was celebrated in 2001. David, biographer of both Brown and Bauer, was uniquely knowledgeable as he joined other systematic botanists at the 'Investigator Symposium' at Albany, Western Australia. There he launched books on Brown (Vallance et al., 2001) and Allan Cunningham (Curry et al., 2001) and also gave the first lectures in a major series.

At the request of the Australian Systematic Botany Society, and with support from the Austrian Government in recognition of Bauer's Austrian nationality, he undertook a remarkable series of lectures on Brown and Bauer at centres around Australia, following the route of the Investigator. Between Albany in December 2001 and Darwin in early 2003, David gave 22 lectures in 16 locations distributed around all Australian states and territories. These were not confined to capital cities but included in Queensland, for example, Gladstone, Townsville, Cairns and Weipa, and were in venues as diverse as a grand meeting room in a major conference centre and the Great Gallery of the Museum of Tropical Queensland in Townsville to outdoors under the stars on the banks of the Pennefather River within sight of a Brown landing site (Fig. 2). The Pennefather (the Coen River of Brown specimens and Flinders' charts) was the site of the only landings by Brown on the mainland of Cape York Peninsula. An expedition team comprising about 20 entomologists, zoologists, ornithologists and a geomorphologist, supported by members of the Royal Geographical Society of Queensland, used Flinders' log, Brown's diary and recent air photographs and satellite imagery to locate the landing sites. The expedition and associated lecture were timed to coincide with the anniversary of the Investigator's visit, and the State Library of New South Wales travelling exhibition Matthew Flinders: The Ultimate Voyage opened at Weipa on the same day. This visit also gave David a chance to become reacquainted with some of the Meliaceae he had worked on many years earlier and to be introduced to a couple of new species in the QRS Herbarium in Atherton (Clarkson, 2002).

As always, David's lectures were wide-ranging, scholarly, lively, splendidly illustrated and with humorous touches - always very well received. In Albany, Sydney and several places in Queensland, he was thrilled to visit areas where Brown had botanised and which were scarcely changed from 200 years earlier. As he described it (Mabberley, 2003) 'perhaps it was Queensland, where I gave more lectures than anywhere else, that had the 'hairs-on-the-back-of-the-neck' experience: to cross by boat with John Clarkson the Pennefather River and to scramble up the shore with 
Robert Brown's list of plants seen there two hundred years before and to be able to tick them off as we moved into the woodlands - it was almost surreal. And on top of that to be the first botanists to collect since he had been there exactly two hundred years before!'In Sydney David's lectures coincided with the Robert Brown 200 Symposium at the Royal Botanic Gardens in May 2002, for which he was a member of the organising committee. The symposium presentations were published in the journals Telopea and Cunninghamia, including his introduction in each case (Mabberley, 2004a, 2004b). This herculean set of lectures, together with his other achievements, led to David being awarded the Nancy T. Burbidge Medal in 2003, the highest honour of the Australasian Systematic Botany Society.

David's involvement with Robert Brown has continued in collaboration with the now late David Moore of the Natural History Museum in London in a decadeslong project to document the types of, and where necessary lectotypify, the species named by Brown (Mabberley \& Moore, in press). This has required lengthy visits to the Museum, and they have collaborated with many botanists, seeking their expertise on individual families and genera.

\section{Sir Joseph Banks and his other protégés}

Sir Joseph Banks was a key figure in European scientific circles, and David has contributed to scholarly studies of his life and work. A recent major publication was on Banks' Florilegium (Gooding et al., 2017), which made available in an affordable format 147 of the copper-plate engravings prepared from Sydney Parkinson's drawings and watercolours made when he and Banks took part in Cook's first voyage to the Pacific (1768-1771). This book won the 2017 James A. Duke Award for Excellence in Botanical Literature from the American Botanical Council, the second such award for a book of which David is an author. David was also involved for many years with the Banks Archive Project, including being a trustee and the Honorary Director. This project is collating and publishing much of Banks' voluminous correspondence, the most relevant in the Australian context being his correspondence about India and the Pacific region (Chambers, 2008-2014).

Brown and Bauer were only two of many men employed by or collaborating with Banks on botanical matters in the late 18th and early 19th centuries. David has researched and written about aspects of the work of others, such as brothers Allan and Richard Cunningham and their connections with the Royal Botanic Gardens Kew, another major interest of Banks (Mabberley, 2000). Banks regarded scientific exploration as being above politics and ensured that some major collections made by scientific expeditions from other European countries were safely delivered to their home institutions or individuals, despite those countries being political enemies of Britain. David has similarly taken an interest in the role of other European collectors and early cultivators of Australian plants, particularly the French, (Mabberley, 1999b, $1999 \mathrm{c}, 2004 \mathrm{c})$. He is currently working on a book about Australian plants cultivated in western Europe in colonial times. 


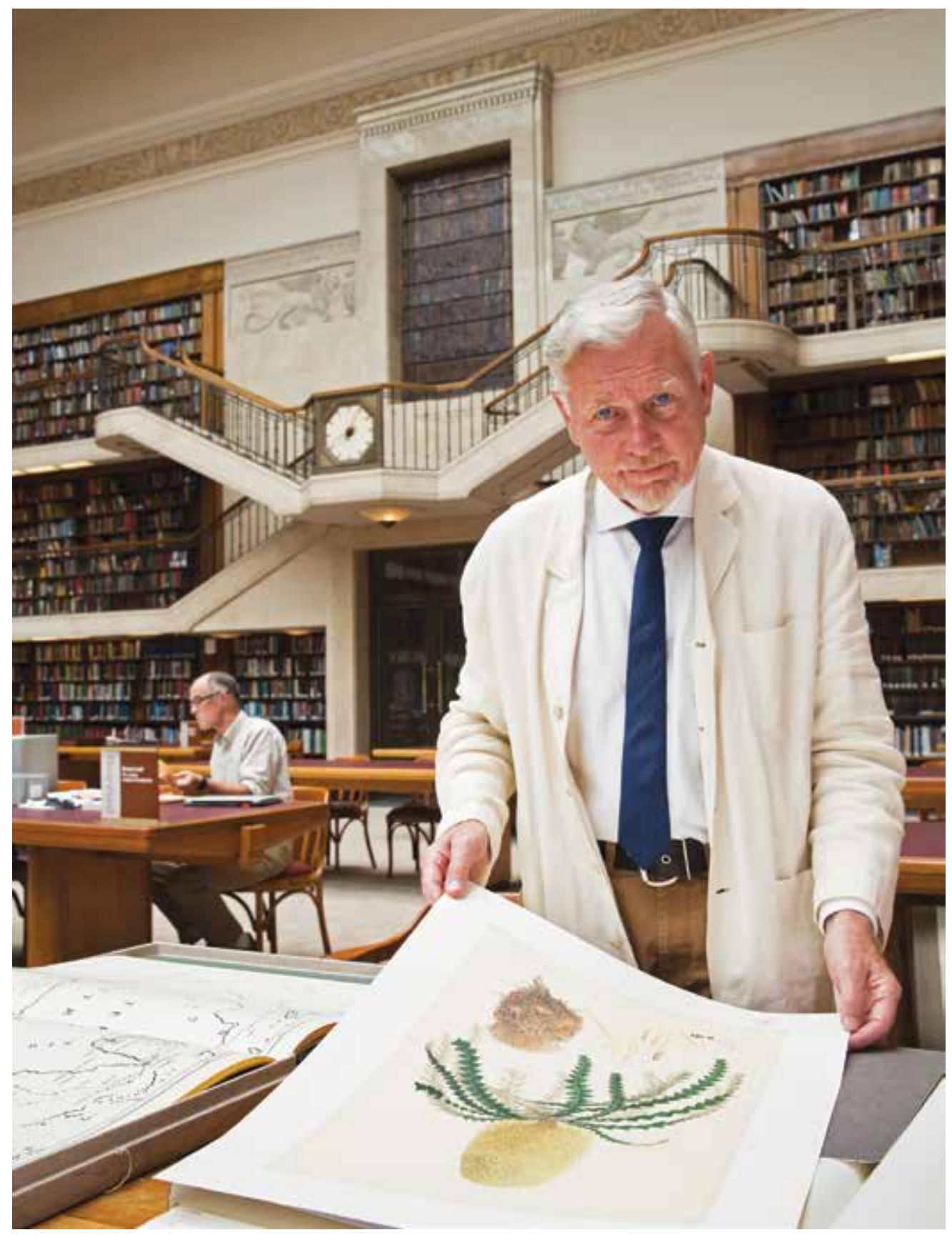

Fig. 1. David examining a Bauer engraving in the State Library of New South Wales in December 2016, in preparation for the exhibition 'Painting by numbers' celebrating the art of Ferdinand Bauer. (Photo: M. Campbell; by courtesy of the State Library of New South Wales, Sydney). 


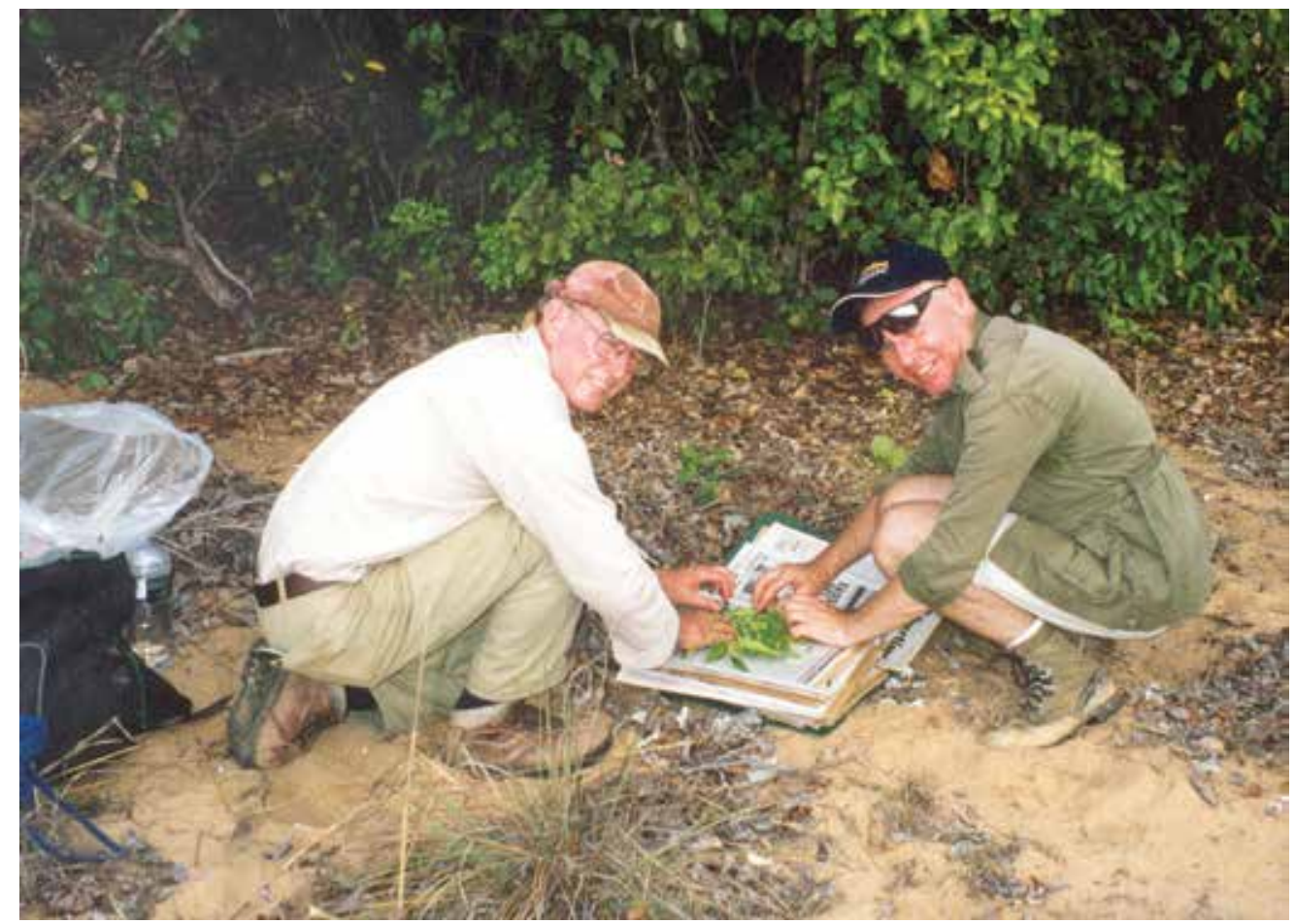

Fig. 2. John Clarkson (left), a botanist with long experience in far north Queensland, organised that part of David's visit to locations from the Investigator voyage and, with David, was pressing specimens at the Pennefather River. (Photo: D. Gillieson).

\section{John Carne Bidwill}

A less well-known person from Australia's botanical history whose life and work David has highlighted is John Carne Bidwill (1815-1853), the first to hold the title of Director of Sydney's Botanic Garden (Mabberley, 1996, 2001a). After studying unpublished manuscripts at the Mitchell Library in Sydney, the Royal Botanic Gardens Kew and elsewhere, David recounted how Bidwill exchanged or sold many plants and seeds he gathered in New Zealand and Australia while collecting for Kew and for other contacts in Britain. Bidwill had been introduced in England by Robert Brown to the Hon. William Herbert, Dean of Manchester and 'the acknowledged expert on plant hybridisation and especially on many petaloid monocotyledons'. Both in Britain and in New South Wales, Bidwill made experiments in hybridisation, especially of Gladiolus and amaryllids (Mabberley, 1996, 2001a). Bidwill is recognised by David as a botanical and horticultural pioneer, but he soon suffered from lack of clarity in the colonial administration. He was appointed as Government Botanist and Director of the Sydney Botanic Garden in September 1847 by the Governor of New South Wales Charles FitzRoy. But in England the Colonial Office had also been seeking a Director and, only a few weeks later, appointed Charles Moore, who was given 
precedence over Bidwill. On Moore's arrival in Sydney, in February 1848, Bidwill unhappily relinquished the position and was appointed later that year as Commissioner of Crown Lands at Wide Bay (in present-day Queensland), but continued importing and exporting plants and seeds on his own account until his early death there in 1853 (Mabberley, 1996, 2001a).

\section{A global reach}

Moving to Australia has not limited David's world-wide interests. In the 1980s, he took on the task of preparing a concise global botanical encyclopedia following from the outdated 'Dictionary of the flowering plants and ferns' (Willis, 1973), a remarkable responsibility that is with him still. The Plant-book (Mabberley, 1987) quickly became internationally accepted as an essential reference text for anyone studying, growing or writing about plants. This was followed by an updated second edition, as Mabberley's Plant-book in 1997 (Mabberley, 1997a), and a third in 2008 (Mabberley, 2008). Mabberley's Plant-Book was recognised in 2004 by the American Society of Plant Taxonomists in the Peter Raven Award for Scientific Outreach to David as a plant systematist who had made exceptional efforts at outreach to non-scientists.

As the book was still in high demand and classifications were changing, especially with new phylogenetic evidence from DNA studies, a further edition was called for. David took on board the new conclusions from the Angiosperm Phylogeny Group $(2009,2016)$, and became a member of the Group, also visiting major botanical institutions to hold discussions with experts on particular plant groups. So the 2017 fourth edition presents a further update, based on the very latest research and checking almost every one of the 26,000 concise entries (Mabberley, 2017b).

As he worked on the Plant-Book, and in other studies, David noticed many instances where names were in use that failed to meet requirements of the International Code of Nomenclature for algae, fungi and plants or that did not reflect current knowledge. New combinations were provided, and so the authority 'Mabb.' features in lists for many plant families. Australian examples are distinctly tropical; among them: Akania bidwillii Mabb. (Akaniaceae), a New South Wales rainforest tree; Proiphys alba (R.Br.) Mabb. and P. cunninghamii (Lind.) Mabb. (Amaryllidaceae), bulbforming herbs of rainforest and rainforest margins; Parsonsia alboflavescens (Dennst.) Mabb. (Apocynaceae), a tropical and subtropical woody vine; Hibiscus fryxellii Mabb. (Malvaceae), a northern Western Australian shrub; Dysoxylum papuanum Mabb. (Meliaceae), a Queensland and PNG timber tree, and D. pumilum Mabb., a Queensland rainforest shrub or small tree; Xylocarpus rumphii (Kostel.) Mabb. (Meliaceae), a widespread tropical tree or shrub; Citrus gracilis Mabb. (Rutaceae), a Northern Territory shrub; and Luvunga monophylla (DC.) Mabb. (Rutaceae), a northern Western Australian spiny shrub or climber. In other cases there is no name with his authorship but he has investigated a complex nomenclatural history, resolving the application of multiple names. An instance is the Agathis brownii case (Araucariaceae) (Mabberley, 2002), which led to lecto- or neo-typifying the names of three species of Agathis and 
one of Dammara, after tracing the history of collecting, planting and naming of several species in Australia, New Zealand, New Caledonia, the Solomon Islands and England.

\section{Plants of economic and cultural significance}

Throughout his career, David has argued against dividing the world and its plants into 'them and us, the wild versus the cultivated' so that 'the study of cultivated plants has been beyond the pale in the snootier of academic circles' (Mabberley, occasional address at Macquarie University graduation 19 September 2018). In discussing the state of systematic botany in Australia (Mabberley, 2012) he emphasised the need to provide the information really needed in our region, including on diseases of economic crops and garden species. The Plant-book includes information on economic and horticultural aspects of plants and this side of David's interests developed further with research and publication on 'the story of the apple' (Juniper \& Mabberley, 2006) as well as a new classification of edible Citrus (Mabberley, 1997b).

A collaboration with Andrew Beattie of Western Sydney University, Randy Bayer, now at the University of Memphis, and others in Australia, Britain and U.S.A. provided new DNA data and analyses of Citrus. These indicated Australia, New Caledonia and New Guinea (rather than southeast Asia) as the region of origin of Citrus and produced a new phylogeny of the Aurantioideae, the subfamily of Rutaceae that includes Citrus and Murraya (Mabberley, 1998a, 2004e, 2016; Bayer et al., 2009). They went on to review the origin and spread of the devastating bacterial disease huanglongbing (also known as citrus-greening) and ways to avoid its introduction to Australia (Beattie et al., 2008a, 2008b, 2010). With commercial citrus crops worldwide, as well as related genera including the ornamental Murraya spp., seriously threatened by this viral disease, this new understanding of relationships is especially important. David's work is referred to in a practical manual for citrus growers (Hardy et al., 2017) and he wrote a popular account to inform Australian horticulturalists of the change in the circumscription of Citrus (Mabberley, 2001b). He used the new phylogeny in his treatment of the aurantioid genera of Rutaceae in the Flora of Australia (Mabberley, 2013).

Another economic example is the valuable timber tree Toona ciliata in the family Meliaceae, known in Australia as Red Cedar. As well as including this in his revisionary and floristic studies on Meliaceae (Mabberley et al., 1995; Mabberley, 1998b), David contributed to an exhibition on Red Cedar at the Museum of Sydney (Mabberley, 2004d).

Further spreading the word about economic botany, for several years David has run a two-day masterclass on economic botany at the Botanic Gardens of South Australia in Adelaide - an intensive series of lectures on the 'biological basis of human society... teaching a far deeper understanding of plants, how they have shaped our past and how they can impact our future.' Philip White (2014), who attended a class, wrote that 'the class included a bright lot of environmental scientists, horticulturers [sic], plant physiologists, other expert plant nerds and people with very big gardens 
to manage... Mabberley took us on a breathless tour through the major food groups, continuously referencing the manner in which we have homogenised and homologated food plants to the point of extreme monoculture, where vital foodstuffs become scarily vulnerable to disease. This is made very much worse with the many plants whose source stocks no longer exist, like citrus, meaning there is no chance of beginning again when our conveniently sanitised and easily-farmed modern forms suddenly succumb to infection... If you ever get a chance to listen to Professor Mabberley, take it.'

\section{Botanical appointments, disappointments and continuing global recognition}

Speaking at Macquarie University when awarded an honorary doctorate in 2018 (Fig. 3), David described his career thus far as having been "exciting, fulfilling and varied" but including "a fair dose of serendipity, setbacks and disappointments". Some of those setbacks and disappointments, as well as great achievements, have come during his time based in Australia.

David has had a long association with the Royal Botanic Gardens and Domain Trust in Sydney. He was a Visiting Research Fellow for several months in 1993, collaborating on a theoretical paper (Mabberley \& Hay, 1994) with Alistair Hay, his former doctoral student and then Horticultural Botanist at the Gardens, as well as revising The Plant-book and researching the Verbenaceae and Lamiaceae of Australia, New Caledonia and New Guinea. The latter studies led to publications, some jointly with other doctoral students, including Mabberley (1993), Steane et al. (1997) and De Kok \& Mabberley (1999). He was appointed as an Honorary Research Associate of the Gardens three years later, when he settled in Sydney.

The retirement of Carrick Chambers as Director of the Sydney Royal Botanic Gardens in 1996 provided an apparent opportunity for a botanist of David's ability, experience and energy, but he was passed over in favour of an appointee without botanical qualifications. (We understand that was by political decision, not by the recommendation of the selection committee.) In the following years, with characteristic energy, he continued research as an Honorary Research Associate of the Sydney Gardens, started his own business, and for some time was CEO for New South Wales of the not-for-profit revegetation organisation Greening Australia.

In 2004 he left Australia to take up the Orin and Althea Soest Chair in Horticultural Science at the University of Washington in Seattle, where he was founding Director of the newly integrated University of Washington Botanic Gardens. In 2008 he was appointed to the position of Keeper of the Herbarium, Library, Art and Archives at the Royal Botanic Gardens Kew. Throughout this time, he continued his link with the Sydney Gardens as an Honorary Research Associate.

In 2011, Tim Entwisle left the directorship in Sydney to be the Director of Conservation, Living Collections and Estates at Kew Gardens. In August 2011, David was appointed as Executive Director of the Royal Botanic Gardens and Domain Trust, with responsibility for the Royal Botanic Garden and the Domain in Sydney, 
the Australian Botanic Garden at Mount Annan, the Blue Mountains Botanic Garden at Mount Tomah and the National Herbarium of New South Wales (Fig. 4). The Foundation and Friends of the Botanic Gardens welcomed him at one of Sydney's most prestigious venues, the state Government House. He outlined his big plans, with priorities including the upcoming bicentennial in 2016 of the founding of the Gardens, PlantBank - for conservation by seed storage - being built at the Australian Garden, and a visitor centre planned for the Sydney Garden. An international peer review was held, a strategic plan was developed, and preparation of a master plan for the Sydney Garden began (Morris, 2015). But always research and publications also continued.

Unfortunately, David's tenure was short-lived. The Executive Director of the Trust is responsible to a Minister of the New South Wales Government and to a Government-appointed body, the Royal Botanic Gardens and Domain Trust. Neither understood the value of a Director with world-wide research interests and, as a result of disagreement as to the Director's role, David resigned from the position in September 2013, and returned to being an Honorary Research Associate of the Gardens. He continued research at the Herbarium in Sydney, with a study also at his home in Mt Victoria, west of Sydney. He was now without research assistance but he was also free from the fetters of a position that, although prestigious, was within the confines of the New South Wales Public Service.

His recognition elsewhere has been very different. He continued to hold an Extraordinary Professorship at the University of Leiden, Netherlands, until he reached the mandatory retirement age in 2018 and has given a course of lectures on economic botany there each year. He is an Emeritus Fellow of Wadham College, Oxford. The Cuatrecasas Medal for excellence in tropical botany was awarded by the Smithsonian Institution in 2004, the Gold Medal for Botany of the Linnean Society of London in 2006, and the Silver Engler Medal of the International Association for Plant Taxonomy in 2009 (for the third edition of the Plant-book). In 2016 he was appointed a Member of the Order of Australia (AM) for, as the official citation said, 'significant service to horticultural science, particularly to plant taxonomy and tropical botany, as an academic, researcher and author'. He is an Adjunct Professor at both Macquarie University in north-western Sydney and Western Sydney University. In 2018 Macquarie University awarded him an honorary doctorate (Doctor of Science honoris causa).

The pace of his work and extent of his international collaborations are exemplified by the Annual Report of the Plant Sciences Branch of the Sydney Gardens in 1998-9. That year, he published a paper on Australian Meliaceae (Mabberley, 1998b), one - with New Zealand co-authors — on the New Zealand kohe-kohe (Braggins et al., 1999), biographical accounts of Robert Brown, Joseph Banks and Wilhelm Petermann, and several publications with colleagues in London, Vienna and Berlin on the botanical art of Ferdinand Bauer. He also prepared a memoir on E.J.H. Corner, who had been his supervisor and mentor at Cambridge. In recent years, he has had up to three monographic publications per year as well as numerous journal papers, and this punishing schedule shows no sign of abating. 


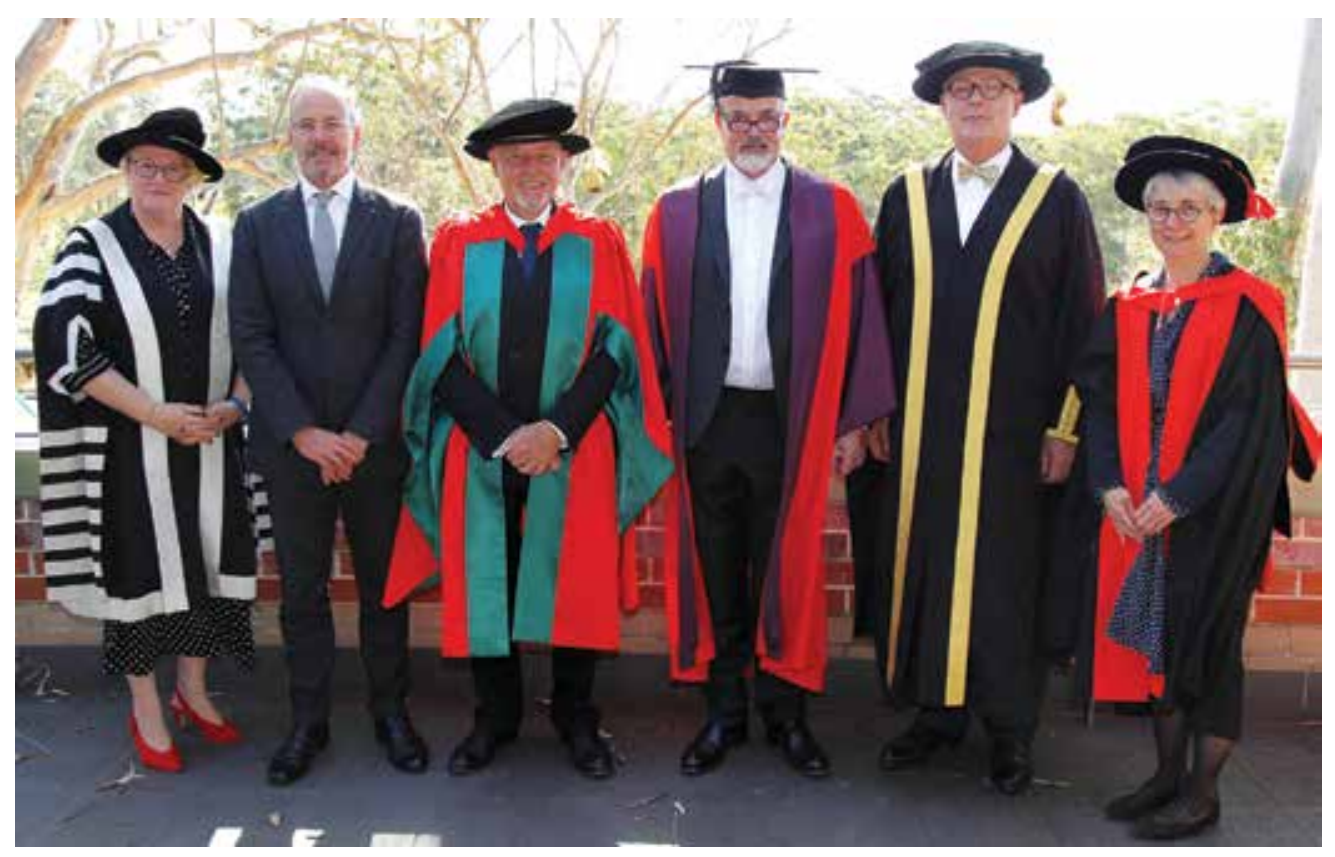

Fig. 3. At Macquarie University, just before David was awarded the degree Doctor of Science honoris causa in September 2018. From the left: Deputy Chancellor Louise Mason, David's partner Andrew Drummond, David, Alistair Hay, Vice Chancellor Bruce Dowton, and Dean of Science and Engineering Barbara Messerle. (Photo: J. Header; by courtesy of Macquarie University).

\section{Systematic botany in Australia}

When David moved to Australia in 1996, he would have met a mix of optimistic and negative sentiments in systematic botany. Botanists everywhere were enthused by the way that world-wide collaborations using molecular data were building phylogenies with levels of support and widespread agreement that were previously beyond our reach. The first of these on the phylogeny of seed plants by Mark Chase and many colleagues (Chase et al., 1993) based on $r b c \mathrm{~L}$, had been published three years earlier. On the other hand, some feared that these new methods would displace their more traditional approaches and would further reduce the limited funding for systematics. Planning for the XVI International Botanical Congress in St Louis in 1999 was in progress, as was organising in Sydney for the Second International Monocots and Third International Grasses joint conferences in 1998.

However, in Australia, by the late 1990s the stimulus that had come from the formation in 1973 of both the Australian (now Australasian) Systematic Botany Society and the Australian Biological Resources Study (ABRS), as well as the International Botanical Congress in Sydney in 1981, had largely evaporated. ABRS had started well with its grants programme and publication of the first volumes of the Flora of 


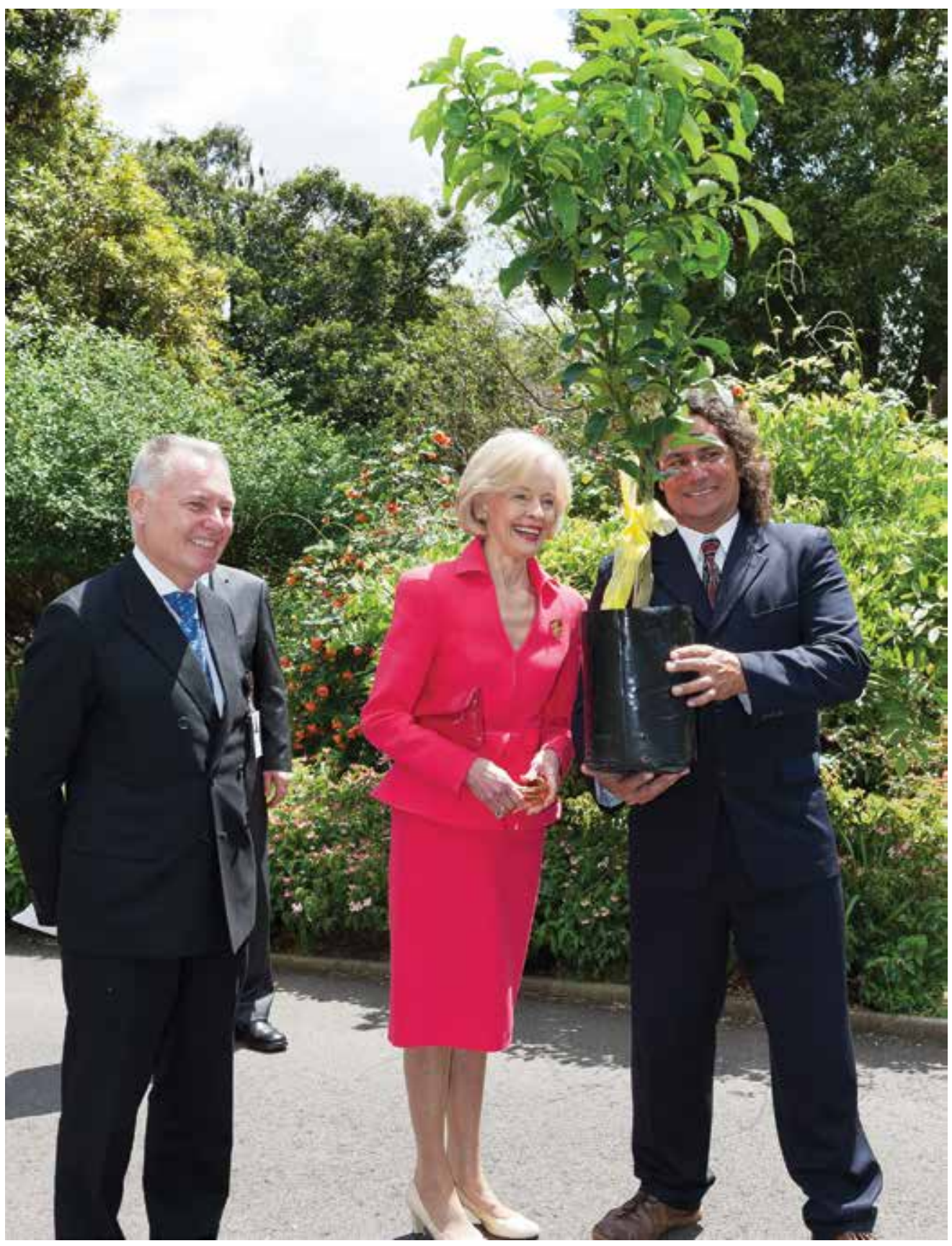

Fig. 4. David with the Honourable Dame Quentin Bryce, at the time Her Excellency the Governor-General of Australia, and Indigenous Education Officer Clarence Slockee in the Royal Botanic Garden Sydney following the launch by Her Excellency of the Australian Year of the Farmer in October 2011. To celebrate the event, Her Excellency planted a pomelo (Citrus maxima) in the Garden's First Farm display. (Photo: J. Plaza; by courtesy of the Royal Botanic Gardens and Domain Trust Sydney). 
Australia (from 1981 onwards), but by the 1990s a considerable number of manuscripts submitted for the Flora, including David's contribution to the Meliaceae, were sitting unpublished with ABRS, awaiting final editing by the too-few editorial staff.

Since then, based in Australia but with visits and fieldwork overseas as his research required, David has seen Australian herbaria strengthen their links with universities, with the energy that co-supervised research students bring to organisations. As elsewhere, there has been ageing of the workforce, with increased reliance on retired botanists continuing their research. Projects to database specimens in Australian herbaria as Australia's Virtual Herbarium (now part of the Atlas of Living Australia) have been effective, as well as the worldwide project funded by the Mellon Foundation to make available on-line images of type specimens. The Australian Plant Census has been a useful development, spearheaded by the Council of Heads of Australian Herbaria. Somewhat better resourcing of the Australian Biological Resources Study and the start of publication of the on-line Flora of Australia in 2018 have brought new optimism among Australian systematic botanists.

At the ASBS conference in Perth in 2012, David's opening address (Mabberley, 2012) focused on whether Australasian systematic botany was meeting the needs of the people of this region. Others were thinking along the same lines and a broad discussion ensued at the conference about how to improve the situation. This led the following year to a panel discussion about the state of systematic botany in Australia and how to address the chronic decline in government support for plant systematics. Among the concerns were the decline in the number of professional botanists employed, cuts to the funding of the Australian Biological Resources Study, and exclusion of non-university organisations from applying for Australian Research Council grants. Similar concerns were felt by Australian zoologists. Discussion about these matters continued until a move to produce a Decadal Plan for Australasian systematics gained support from the Australian Academy of Science. This culminated in the Plan launched in April 2018 (Taxonomy Decadal Plan Working Group, 2018) which expresses very positively the role, impact and aims of plant systematics in Australia.

\section{A career of Australian and global achievement}

Australia is fortunate that so distinguished a botanist as David Mabberley has chosen this country as his home. He has researched and published (and continues to do so) on botanists and botanical artists significant to Australia, he has contributed to the Flora of Australia and studied Australian plants and allied species in neighbouring Malesia, New Caledonia and New Zealand. He has established research collaborations with Australian botanists. In Australia he has spoken about botany in lectures (Fig. 5) and on radio, contributed to botanical exhibitions, and continued to publish on numerous botanical subjects. He has received the highest award of the Australasian Systematic Botany Society among many other honours. His stature has drawn attention to Australia on the worldwide botanical stage. These achievements would have been notable and sufficient for most botanists. 


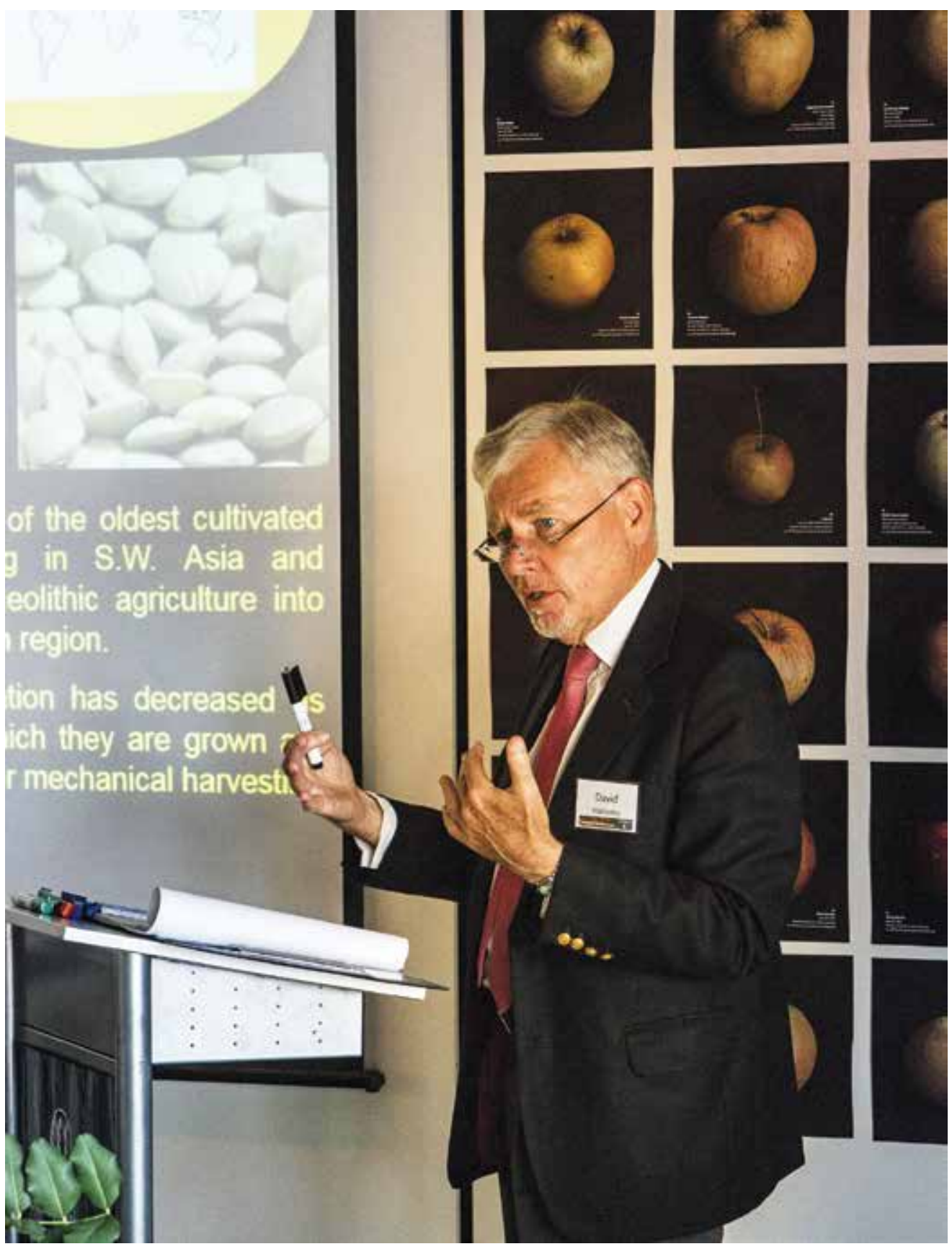

Fig. 5. David lecturing about economic botany at the Adelaide Botanic Garden, in October 2014. (Photo: T. Chladek; by courtesy of the Botanic Gardens and State Herbarium of South Australia, Adelaide). 
But David is not limited to Australia. His main botanical contributions are in the global compendium Mabberley's Plant-book, his studies and publications on tropical botany and plants of economic significance, and on historical figures such as Robert Brown and Ferdinand Bauer, and in his leadership of international organisations such as the International Association for Plant Taxonomy and the Society for the History of Natural History. Speaking in 2002 (Mabberley, 2004a), David reminded Australian botanists that, although they tended to regard Robert Brown as a primarily 'Australian' botanist, Brown's reach was global in scale. 'In Australia we tend to grasp to us Brown, like Bentham later, for his work on our flora, but both men worked monographically and therefore beyond the phytogeographical constraints of Australia.' And 'to show his truly global influence, it is important that we realise he [Brown] worked on a flora as distant as it could be from Australia: the Arctic'. Similarly, David Mabberley has contributed, and continues to contribute, much to Australian botany but his magnificent contribution extends far beyond Australia and is truly global in reach. Long may it continue!

\section{References}

Angiosperm Phylogeny Group (2009). An update of the Angiosperm Phylogeny Group classification for the orders and families of flowering plants: APG III. Bot. J. Linn. Soc. 161: 105-121.

Angiosperm Phylogeny Group (2016). An update of the Angiosperm Phylogeny Group classification for the orders and families of flowering plants: APG IV. Bot. J. Linn. Soc. 181: 1-20.

Bayer, R.J., Mabberley, D.J., Morton, C., Miller, C.H., Sharma, I.K., Pfeil, B.E., Rich, S., Hitchcock, R. \& Sykes, S. (2009). A molecular phylogeny of the orange subfamily (Rutaceae: Aurantioideae) using nine cpDNA sequences. Amer. J. Bot. 96: 668-685.

Beattie, G.A.C., Holford, P., Mabberley, D.J., Haigh, A.M. \& Broadbent, P. (2008a). Australia and huanglongbing. In: Ku, T.Y. \& Pham, T.H.H. (eds) Proceedings of FFTC-PPRINIFTS Joint Workshop on Management of Citrus Greening and Virus Diseases for the Rehabilitation of Citrus Industry in the ASPAC, Plant Protection Research Institute, Hà Nội, Việt Nam, 8-12 September 2008, pp. 75-100.

Beattie, G.A.C., Holford, P., Mabberley, D.J., Haigh, A.M., Bayer, R. \& Broadbent, P. (2008b). Origins of Citrus, huanglongbing and the Asiatic citrus psyllid. Proceedings of the Sixth Việtnam Conference on Entomology, 9-10 May 2008, Hà Nội, Việt Nam, pp. 820-834.

Beattie, G.A.C., Holford, P., Mabberley, D.J., Haigh, A.M. \& Broadbent, P. (2010). Australia and huanglongbing. Food and Fertilizer Technology Center for the Asian and Pacific Region Bulletin.

www.fftc.agnet.org/htmlarea_file/library/20110711155826/eb607.pdf. Accessed 21 Feb. 2019.

Braggins, J.E., Large, M.F. \& Mabberley, D.J. (1999). Sexual arrangements in kohekohe (Dysoxylum spectabile, Meliaceae). Telopea 8: 315-324.

Brown, R. (1810a). Prodromus florce Nova Hollandice et Insulce Van-Diemen: exhibens characteres plantarum quas annis 1802-1805. London: R. Taylor. 
Brown, R. (1810b). On the Proteaceae of Jussieu. Trans. Linn. Soc. London. 10: 15-226.

Brown, R. (1814). General remarks, geographical and systematical, on the botany of Terra Australis. In: Flinders, M. A voyage to Terra Australis, vol. 2, pp. 533-612, tt. 10. London: G. \& W. Nicol.

Brown, R. (1826). Character and description of Kingia; a new genus of plants found on the south-west coast of New Holland. With observations on the structure of its unimpregnated ovulum, and on the female flower of Cycadeae and Coniferae. London.

Brown, R. (1830). Supplementum primum prodromi florae Novae Hollandiae: exhibens Proteaceas novas quas in Australia legerunt DD. Baxter, Caley, Cunningham, Fraser et Sieber; et quarum e siccis exemplaribus characteres elaboravit Robertus Brown. London.

Brown, R. (1831). General view of the botany of the vicinity of Swan River. J. Geogr. Soc. London 1: 17-21.

Brown, R. (1848). Botanical appendix to Captain Sturt's expedition into Central Australia. [Preprint of appendix] In: Sturt, C. (1849) Narrative of an expedition into Central Australia during the years 1844, 1845 and 1846, vol.2, pp. 64-92. London.

Chambers, N. (ed.) (2008-2014). The Indian and Pacific correspondence of Sir Joseph Banks, 1768-1820. 8 vols. London: Pickering \& Chatto Publishers.

Chase, M.W., Soltis, D.E., Olmstead, R.G., Morgan, D., Les, D.H., Mishler, B.D., Duvall, M.R., Price, R.A., Hills, H.G., Qiu, Y.-L. et al. (1993). Phylogenetics of seed plants: an analysis of nucleotide sequences from the plastid gene $r b c$ L. Ann. Missouri Bot. Gard. 80: $528-580$.

Clarkson, J. (2002). Marking the Robert Brown bicentenary, celebrations in far north Queensland. Austral. Syst. Bot. Soc. Newslett. 113: 30-33.

Curry, S., Maslin, B.R. \& Maslin, J.A. (2001). Allan Cunningham - Australian collecting localities. Canberra: ABRS Publications.

De Kok, R.P.J. \& Mabberley, D.J. (1999). The genus Faradaya (Labiatae). Blumea 44: 321342.

Gooding, M., Mabberley, D.J. \& Studholme, J. (2017). Joseph Banks' Florilegium: Botanical Treasures from Cook's First Voyage. London and New York: Thames \& Hudson.

Hardy, S., Barkley, P., Treeby, M., Smith, M. \& Sanderson, G. (2017). Australian mandarin production manual. New South Wales Department of Primary Industries.

Juniper, B.E. \& Mabberley, D.J. (2006). The Story of the Apple. Portland and Cambridge: Timber Press.

Jussieu, A.L. de (1789). Genera plantarum secundum ordines naturales disposita. Paris: V. Herissant \& T. Barrois.

Mabberley, D.J. (1983). Tropical rain forest ecology. Glasgow: Blackie.

Mabberley, D.J. (1985). Jupiter botanicus. Robert Brown of the British Museum. Braunschweig: Cramer and London: British Museum (Natural History).

Mabberley, D.J. (1987). The Plant-book. A portable dictionary of the higher plants. Cambridge: Cambridge University Press.

Mabberley, D.J. (1991). Tropical rain forest ecology, $2^{\text {nd }}$ edition. Glasgow: Blackie.

Mabberley, D.J. (1993). Architecture of Verbenaceae of Madang Province, Papua New Guinea, with preliminary notes on their reproductive biology. Sci. New Guinea 19: 37-45.

Mabberley, D.J. (1996). Plant introduction and hybridisation in colonial New South Wales: the work of John Carne Bidwill, Sydney's first director. Telopea 6: 541-562.

Mabberley, D.J. (1997a). The Plant-book. A portable dictionary of the vascular plants, $2^{\text {nd }}$ edition. Cambridge: Cambridge University Press. 
Mabberley, D.J. (1997b). A classification for edible Citrus (Rutaceae). Telopea 7: 167-172.

Mabberley, D.J. (1998a). Australian Citreae with notes on other Aurantioideae (Rutaceae). Telopea 7: 333-344.

Mabberley, D.J. (1998b). Notes on Australian Meliaceae. Telopea 8: 47-48.

Mabberley, D.J. (1999a). Ferdinand Bauer: the nature of discovery. London: Merrell Holberton $\&$ The Natural History Museum.

Mabberley, D.J. (1999b). The importance to Indopacific botany of Baron Dumont de Courset's Botaniste cultivateur. Gard. Bull. Singapore 51: 309-317.

Mabberley, D.J. (1999c). 'Robert Brown's' Parisian Podolepis. Telopea 8: 297-298.

Mabberley, D.J. (2000). The Botanical Magazine and George Bond's drawings of Allan Cunningham's Australian plants. Curtis's Bot. Mag. 17: 226-235.

Mabberley, D.J. (2001a). Bidwill of the Bunya-Bunya. Curtis's Bot. Mag. 18: 31-46.

Mabberley, D.J. (2001b). Citrus reunited. Austral. Pl. 21: 52-54.

Mabberley, D.J. (2002). The Agathis brownii case (Araucariaceae). Telopea 9: 743-754.

Mabberley, D.J. (2003). David Mabberley's acceptance speech [accepting the Nancy Burbidge Medal]. Austral. Syst. Bot. Soc. Newslett. 116: 2-3.

Mabberley, D.J. (2004a). Robert Brown 200: Introduction. Telopea 10: 497-498.

Mabberley, D.J. (2004b). Robert Brown 200: Introduction. Cunninghamia 7: 613-615.

Mabberley, D.J. (2004c). More French 'firsts' in Australia ignored: Dumont de Courset's Le Botaniste Cultivateur. Taxon 53: 187-192.

Mabberley, D.J. (2004d). European discovery, description and naming. In: McPhee, J. (ed.) Red cedar in Australia, pp. 22-41. Sydney: Historic Houses Trust of New South Wales.

Mabberley, D.J. (2004e). Citrus (Rutaceae): a review of recent advances in etymology, systematics, and medical applications. Blumea 49: 481-498.

Mabberley, D.J. (2008). Mabberley's plant-book: A portable dictionary of plants, $3^{\text {rd }}$ edition. Cambridge: Cambridge University Press.

Mabberley D.J. (2012). Whither Australian plant systematics? Austral. Syst. Bot. Newslett. 153: 32-38.

Mabberley, D.J. (2013). Rutaceae Group 4. In: Wilson, A.J.G. (ed) Flora of Australia, vol. 26, pp. 496-510. Canberra: ABRS; and Melbourne: CSIRO Publishing.

Mabberley, D.J. (2016). The typification of Murraya, M. exotica, and M. paniculata (Rutaceae): its significance for the world citrus industry. Taxon 65: 366-371.

Mabberley, D.J. (2017a). Painting by numbers, the life and art of Ferdinand Bauer. Sydney: University of New South Wales Press.

Mabberley, D.J. (2017b). Mabberley's plant-book: A portable dictionary of plants, $4^{\text {th }}$ edition. Cambridge: Cambridge University Press.

Mabberley, D.J. \& Hay, A. (1994). Homoeosis, canalization, decanalization, 'characters' and angiosperm origins. Edinburgh J. Bot. 51: 117-126

Mabberley, D.J., Pannell, C.M. \& Sing, A.M. (1995). Meliaceae. Flora Malesiana, ser. 1, vol. 12, pt. 1. Leiden: Rijksherbarium.

Mabberley, D.J. \& Moore, D.T. (1999). Catalogue of the holdings in the Natural History Museum (London) of the Australian botanical drawings of Ferdinand Bauer (1760$1826)$ and cognate materials relating to the Investigator voyage of 1801-1805. Bull. Nat. Hist. Mus. London, Bot. 29: 81-226.

Mabberley, D.J. \& Moore, D.M. (in press). The Robert Brown Handbook. Regnum Vegetabile 160.

Morris, C. (2015). History and evolution. In: Churchill, J. (ed.) The Royal Botanic Garden Sydney: the first 200 years, pp. 27-49. Ultimo and Braddon: Halstead Press. 
Pignatti-Wikus, E., Riedl-Dorn, C., \& Mabberley, D.J. (2000). Ferdinand Bauer's field drawings of endemic Western Australian plants made at King George Sound and Lucky Bay, December 1901 — January 1802. I: Families Brassicaceae, Goodeniaceae p.p., Lentibulariaceae, Campanulaceae p.p., Orchidaceae, Pittosporaceae p.p., Rutaceae p.p., Stylidiaceae, Xyridaceae. Rend. Fis. Acc. Lincei, ser. 9, 11: 69-109.

Steane, D.A., Scotland, R.W., Mabberley, D.J., Wagstaff, S.J., Reeves, P.A. \& Olmstead, R.G. (1997). Phylogenetic relationships of Clerodendrum s.l. (Lamiaceae) inferred from chloroplast DNA. Syst. Bot. 22: 229-243.

Stearn, W.T. (1960). An introduction to Robert Brown's 'Prodromus Florae Novae Hollandiae'. In: Brown, R. Prodromus Florae Novae Hollandiae et insulae van Diemen. Facsimile. New York: Engelmann and Weldon \& Wesley.

Taxonomy Decadal Plan Working Group (2018). Discovering biodiversity: a decadal plan for taxonomy and biosystematics in Australia and New Zealand 2018-2027. Canberra and Wellington: Australian Academy of Science \& Royal Society Te Apārangi.

Vallance, T.G., Moore, D.T. \& Groves, E.W. (2001). Nature's Investigator: The diary of Robert Brown in Australia 1801-1805. Canberra: ABRS Publications.

Watts, P., Pomfret, J.A. \& Mabberley D.J.(1997). An exquisite eye: The Australianflora and fauna drawings 1801-1820ofFerdinandBauer. Glebe:HistoricHousesTrustofNewSouth Wales.

White, P. (2014). Amazing days with David Mabberley. https://drinkster.blogspot. com/2014/11/amazing-days-with-david-mabberley.html. Accessed 21 Feb. 2019.

Willis, J.C. (1973). A dictionary of the flowering plants and ferns, $8^{\text {th }}$ edition, revised by Airy Shaw, H.K., reprinted 1980. Cambridge: Cambridge University Press. 